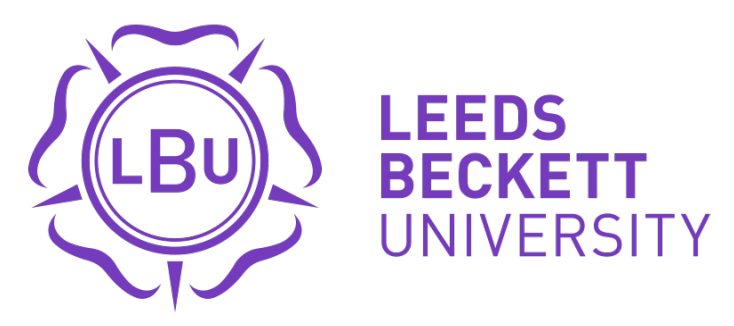

Citation:

Samy, M and Ogiri, $\mathrm{HI}$ and Bampton, R (2015) Examining the public policy perspective of CSR implementation in Sub-Saharan Africa. Social Responsibility Journal, 11 (3). 553 - 572 . ISSN 1747-1117 DOI: https://doi.org/10.1108/SRJ-02-2013-0009

Link to Leeds Beckett Repository record:

https://eprints.leedsbeckett.ac.uk/id/eprint/1765/

Document Version:

Article (Accepted Version)

The aim of the Leeds Beckett Repository is to provide open access to our research, as required by funder policies and permitted by publishers and copyright law.

The Leeds Beckett repository holds a wide range of publications, each of which has been checked for copyright and the relevant embargo period has been applied by the Research Services team.

We operate on a standard take-down policy. If you are the author or publisher of an output and you would like it removed from the repository, please contact us and we will investigate on a case-by-case basis.

Each thesis in the repository has been cleared where necessary by the author for third party copyright. If you would like a thesis to be removed from the repository or believe there is an issue with copyright, please contact us on openaccess@leedsbeckett.ac.uk and we will investigate on a case-by-case basis. 


\section{Examining the public policy perspective of CSR implementation in sub-Saharan Africa}

\section{Background}

In recent years, there has been an increase in the number of countries adopting a national policy for Corporate Social Responsibility (CSR) practice, particularly in western society. Despite the growing awareness about the role of government in CSR promotion, governments in subSaharan Africa are among many developing and poorer countries that are yet to evolve national policies that could help promote CSR in the region (KPMG, 2011; Visser and Tolhurst, 2010; Kivuitu and Yambayamba, 2004). As drivers of CSR, governments hold resources, such as access to regulated parts of society that makes the inclusion of CSR opportunities relevant to strategic and operational management (Breitbarth et al, 2009). From the extant literature, the role of government in defining and shaping the field of CSR is gaining wider acceptability. For instance, Steurer (2010), Albareda et al (2008), Mendibil et al (2007), Adeyeye (2011) and Fox et al (2002) in their various studies, highlighted the role of government as a major determinant in any CSR framework, since it has the moral authority to intervene to deliver a framework through which businesses can act and behave in a responsible way (see also Sun et al, 2010). Furthermore, most of the CSR studies conducted so far have been in the context of developed countries such as Western Europe, the U.S.A, and Australia and little is known about the practice in ex-colonial, smaller, and emerging countries (Jamali and Mirshak, 2007). At the centre of this growing popularity of CSR in western society is the role of government mandating, partnering, facilitating and endorsing roles (Bichta, 2003; Ite, 2007a).

Countries all over the world are establishing necessary institutional frame-works and structures to support CSR practice and reporting. As noted by Utama (2007), since companies naturally tend to present a biased view of their CSR activities, reporting only positive aspects, the role of regulator is to establish infrastructures that support accountable CSR reporting. Studies have shown that the reason why CSR is absent in less developed countries is due to the fact that there are numerous obstacles to achieving corporate responsibility because the institutions, guidelines and appeals system, which give life to CSR in North America and Europe, are relatively weak in many developing countries (Chambers, et al 2003). In most developing countries including sub-Saharan African countries, the aforementioned institutional conditions are often an exception. There are both no legal and regulatory frameworks for Multinational Corporation activities and their socio- ecological impact, or such regulations may exist but are not adequately enforced (Rwabizambuga, 2007). This situation, unfortunately, has 
created a huge reporting gap between what organizations do and what they report regarding CSR.

\section{Literature Review}

\subsection{Contextual perspectives}

Since 1998, The World Business Council for Sustainable Development (WBCSD) dialogues with diverse stakeholders throughout the world have revealed that CSR means very different things to different people, depending upon a range of local factors including culture, religion, and governmental or legal framework conditions. There can be no universal standard. In Europe, according to Perrini (2007 p 25), '’member states are trying to adjust the commission's guidelines to the unique characteristics and aspects of each country that affect CSR - structural, cultural, institutional, civil society etc...’’.

While CSR may have some converged principles across the world such as universal human rights, the practical perception of CSR is always embedded in a societal context of place and time (Sun et al, 2010, Muthuri, 2012). In Africa, CSR is framed within ethics of slavery, colonialism and apartheid (Muthuri, 2012), driven by the need to address social injustice and inequality within society. More recently, in the developing country context, CSR is equated with philanthropy, gifts, or donations (Lin-Hi, 2010) as it was not originally embedded in the socio-cultural system of governance. The advent of MNCs occasioned by globalization, introduced CSR as a relatively new phenomenon in management and governance circles in developing countries (Helg, 2007), thus increasing the need to comply with international codes of business conduct.

An important consideration in CSR implementation in the developing country context is the issue of legislation. In Nigeria, for instance, the debate on whether CSR should be catered for by law or one that should be left to individuals and organisations morality has long been disputed (Mordi et al, 2012). While the importance of self-regulation and codes of conduct as the main instruments of voluntary rule-setting has long been embraced (Kolk and Tulder, 2002), a recent study by Ikejiaku (2012) show that it is more practicable for certain 'salient CSR issues' to be 'distinctly' mandatorily regulated, while other non-salient CSR issues be allowed to remain voluntary. According to Reed (2002), for a self-regulatory approach to be compatible with responsible business, some combination of three conditions must hold: (a) market pressure must force businesses to operate in such a way that they fulfil their responsibilities, (b) businesses must be inclined to fulfil their obligations out of ethical motivation, and/or (c) there must be strong stakeholder pressure to encourage business to take up its responsibilities. These conditions are often absent in most of sub-Saharan African 
countries, indicating the need for government involvement in CSR promotion. The next section examines this imperative.

\subsection{Role of government}

One of the least researched, yet strategically important issues in the emerging field of CSR is the relationship between CSR and the public policy frameworks or governance context within which companies are operating - locally, nationally and globally (Nelson, 2008). Defining a comprehensive model for CSR in Africa is problematic, not only because CSR is in its infancy, but also because it tends to be characterized by ad hoc projects focused on the community level and driven by the dominant cultural context of the individual countries within the region (Visser and Tolhurst, 2010).

Government has a role in CSR promotion (Albareda, 2008). From the industrial revolution to recent years, social objectives have been almost entirely the responsibility of government (Bichta, 2003). According to Bichta (2003), legislation, regulation and taxation have been the favourable tools employed by government to promote and protect social objectives. According to Visser and Tolhurst (2010, p.8), "there is no comprehensive or concrete CSR policy or law in most countries in sub-Saharan Africa region, apart from some rather ad hoc legislative and non-regulatory activities”.

While most of the research studies that have been conducted in the CSR field in subSaharan Africa have focused on corporations voluntary CSR initiatives (Amaeshi et al, 2006; Adeyanju, 2012; Vertigans, 2012; Eweje, 2007; Tuodolo, 2009; Obalola, 2008), only a few studies have highlighted the need for government involvement in CSR promotion (Idemudia, 2010; Mordi et al, 2012; Uwuigbe and Egbide, 2012). A study by Hamann and Acutt (2003) suggests that the government should take a more active role in shaping the CSR agenda by ensuring that partnerships and voluntary initiatives are relevant and complementary to regulatory goals. Such roles (i.e. mandating, facilitating, partnering and endorsing) are well embedded in Stuerer (2010) CSR policies typology which involve raising awareness, improving disclosure transparency, fostering socially responsible investment, and leading by example (see also Joseph, 2002).

The growth in the level of awareness about the importance of CSR has seen an increasing amount of research highlighting the need for national policy frameworks that will assist corporations in embedding CSR in their overall business objectives. For example, Bichta (2003); Standing (2007); Young and Marais (2011) have, in their various studies called for national CSR policies through regulation. Furthermore, Emeseh et al (2010), argue that the non-regulation of MNCs regarding their social and environmental responsibility has potential 
serious consequences, albeit on the more powerless and voiceless sections of the global community. Referring to the 2009 global financial crisis, Emeseh et al (2010 p.259) note that "if corporations have, through personal greed and irresponsibility, so evidently failed to regulate themselves even in their core areas of business necessary for their own survival, how much less do we expect of effective self-regulation in the area of CSR, which is currently purely under a regime of voluntarism?’'.

According to Visser and Tolhurst (2010), the involvement of government (e.g. through regulations, incentives or support for CSR dialogues) was deemed critical in successful CSR projects. Example of countries that have established some CSR related initiatives include: Sweden (mandated Global Reporting Initiative (GRI) reporting by state-owned companies), Denmark (green account requirement), German government ‘Action plan’ for CSR, Indonesia (corporation law including reporting on social and environmental responsibility), MVO (CSR) Netherlands, among others (see Utama, 2007; Roser and Edwin, 2010; Mehallow, 2010; Joseph, 2002; The crystal, Transparency Benchmark, 2010; Global Reporting Initiative, 2010).

In sub-Saharan Africa, the lack of a CSR regulatory body has created a huge implementation problem of CSR polices. For instance, Newell (2005) argue that a significant limitation of many existing CSR approaches is that while they encourage 'responsible' business to go beyond compliance; they provide few checks and balance on the operations of irresponsible business for which strategies of regulation, sanction and protest continue to be key drivers of change. In Ghana, for instance, communications experts have vigorously campaigned for the government to set up a National CSR framework, to define parameters for CSR in the country (Selby and Kunateh, 2009).

The European Commission (2011) report on CSR suggests that public authorities play a supporting role through a smart mix of voluntary policy measures and, where necessary, complementary regulation, for example to promote transparency, create market incentives for responsible business conduct, and ensure corporate accountability. Apart from initiating a CSR policy framework, government, as the biggest spender in any economy, can effectively influence CSR practice by companies. For instance, a company which is dependent on government contracts and projects will also try to convince the stakeholders of how committed they are in terms of addressing social and environmental issues (Amran and Devi, 2007).

In an attempt to fill the gap(s) in the literature, this paper examined the extent to which governments in sub-Saharan Africa formulate and implement national CSR policies aimed at promoting the practice, and also highlights the motivational factors and characteristics of CSR implementation in the sub-region. 


\section{Research Methodology}

According to Hale et al (2007), qualitative research is particularly appropriate when you want to understand or obtain an account of a personal perspective of an event or experience. As a qualitative research, the method adopted is the interpretive paradigm, the grounds which lie in the need to grasp the meaning of social action in the context of the life - world and from actors' perspective (Vasilachis de Gialdino, 2011). It is, therefore, believed that the best way to understand any phenomenon is to view it in its context (Krauss, 2005). The criteria for selecting the interpretive epistemology is that, firstly, there was no deterministic perspective imposed by the researchers, secondly; participants' perspectives were taken as the primary sources of understanding and investigating the phenomena; and finally, the phenomena was examined with respect to culture and contextual circumstances (Chen and Hirschheim, 2004). Data was sourced from notable participants including Ministers and MPs in the respective countries, thus providing data which consisted of detailed descriptions of the phenomenon being studied in ways which further provide depth and detail (Adegbite et al, 2012).

This research was located in sub-Saharan Africa including Nigeria, Ghana and South Africa. South Africa was selected because it is the only country in Africa among the top ten countries in the world where corporations are sharing their reports with the GRI (Rea, 2011), in addition to its recorded success in CSR practice (GRI, 2011). For Nigeria and Ghana, though without strong CSR practice history, these countries were chosen for the study because of their relatively strong economies (with lots of potential investors), relatively stable democratic governance (Boafo-Arthur, 2008; Idowu, 2008; Sharif, 2010) and their cultures and value system which aided the researcher (especially in terms of access) for the interview quest. The study employed largely primary data for the analysis. The data were sourced through interviews of selected participants. This researchers visited the selected countries; Nigeria, Ghana and South Africa, and conducted semi-structured and in-depth face-to-face interviews. In locating the interviewees who have had experiences related to the study phenomenon, the researcher made use of internet searches (i.e. e-mails, twitter, etc.), and telephonic inquiry to the offices of the ministries/national parliamentary committees of foreign affairs, economic affairs, trade, environment, employment and labour, finance, transport and infrastructure, social and rural affairs in each of the selected countries outlining the research agenda. The list of respondents and their designations are listed below in table 1.

Table 1 Profile of interview participants 


\begin{tabular}{|lllll|}
\hline S/N & Participants & Country & Designation & Ministry/ Department/Committee \\
\hline & Code & & & membership \\
\hline 1 & NG 1 & Nigeria & MP & Chm committee on Environment \\
\hline 3 & NG 2 & Nigeria & MP & Member, Environment, oil \& gas \\
\hline 4 & NG 3 & Nigeria & Executive & Director, Standard org of Nigeria \\
\hline 5 & NG 5 & Nigeria & MP & Social Affairs, Envir., oil \& gas \\
\hline 6 & GH 1 & Ghana & Executive & MP/Dep. Minister, Trade \& Industry \\
\hline 7 & GH 2 & Ghana & Executive & MP/Dep. Minister, Social Affairs \\
\hline 8 & GH 3 & Ghana & MP & Member, Environment committee \\
\hline 9 & GH 4 & Ghana & MP & Member, Local Government cmtte \\
\hline 10 & GH 5 & Ghana & MP & Member, Trade \& Industry cmtte \\
\hline 11 & SA 1 & S. Africa & MP & Dep. Chief Whip \& member committee \\
\hline & & & & On Social Affairs \\
\hline 12 & SA 2 & S. Africa & MP & Member, Social Affairs committee \\
\hline 13 & SA 3 & S. Africa & MP & Member, Environment committee \\
\hline 14 & SA 4 & S. Africa & MP & Member, Social Affairs committee \\
\hline 15 & SA 5 & S. Africa & Executive & Minister for Transport \& Public \\
\hline & & & & Works (Western Cape Province) \\
\hline
\end{tabular}

The study adopted procedures meant to ensure compliance to ethical standards. Prior to commencing the interviews with selected participants, a consent agreement form was designed and e-mailed to selected participants for them to study and understand their rights and obligations concerning the interviews. Confidentiality and anonymity of participants were assured as the researcher also explained to individual participants that their names will not be shown in the study schedules. Instead, pseudo names were designed to replace participants' real names as a means of concealing their identities.

Interviews were conducted with top government functionaries (policy makers and policy implementers) in the category of MPs and cabinet members charged with CSR related functions. While MPs were generally consisted of members of National parliaments of the selected countries, cabinet members consisted of Ministers, Special Advisors, Heads of Departments, Directors-General or their equivalents at the national level of respective governments. The reason for choosing these category of officials is that "in qualitative research, participants are usually recruited to a study because of their exposure to or their experience of the phenomenon in question” (Ryan, et al 2007 p.741). According to Saunders et al (2009), semi-structured and in-depth interviews provide the researcher with the 
opportunity to 'probe' answers, where the researcher wants the interviewees to explain, or build on, their responses (p.324). Furthermore, Hignett and Wilson (2004), suggests that semistructured interviews can be video-taped and later transcribed verbatim in preparation for analysis. Also, the semi-structured interview method was considered appropriate since this research used NVivo9 for the data analysis which required data transcription. An obvious but important step in phenomenological analysis of interview data is to have the interview tapes transcribed (Hycner, 1985). Evidence for the study was derived from the perceptions of key government officials within the cabinet and parliamentary portfolios.

In all, fifteen participants (i.e. five participants in each of the three countries) participated in this project. In achieving the targeted number of fifteen participants, the research employed the 'purposive’ sampling in deciding the sample size (see Devers and Frankel, 2000). The purposive sampling was chosen because it is considered as the most important kind of nonprobability sampling, to identify primary participants (Groenewald, 2004). According to Russell and Gregory (2003), most qualitative studies use purposeful (or purposive) sampling, a conscious selection of a small number of data sources that meet particular criteria. Qualitative research uses purposive sampling as opposed to random sampling. As Bowen (2005) notes, 'because the emphasis is on quality rather than quantity, the objective is not to maximize numbers but to become saturated with information on the topic’' (p.217). In fact, a very large number of respondents can be expected to hinder the researcher's ability to get ''in-depth'” and miss the opportunity of getting an understanding of each respondent (Fink, 2000 p.4). And as noted by Hignett and Wilson (2004), purposive sampling result in interviews with a small number of people with specific characteristics or experience in the area of study (see also Ryan et al, 2007).

The data collected through interviews was analysed using the analytic induction approach. According to Bowen (2005), the analysis of interview transcripts and field notes is based on an inductive approach geared to identifying patterns in the data by means of thematic codes. However, before the data was analysed, it was first transcribed from the recorded audio to text. With the permission of the interviewees, all interviews were recorded on separate tapes and labelled with an assigned code to each interview (see, for example, Groenewald, 2006; Bowen, 2005; Fin, 2000). The NVivo9 software was used to conduct the analysis. Interview transcripts were subjected to open coding in NVivo9 of issues relating to the interviewee's perception of the characteristics of the various government focused CSR policy frameworks (see Pedersen, 2011). The coding of the interviews was guided by a list of predefined issues, themes, and categories that were developed by the researcher after the interviews had been 
carried out and transcribed. The coding list covered key issues from the interview guideline and more specific categories that emerged during the data collection process. Thematic Analysis method was used for identifying; analysing and reporting patterns (themes) within data (see Braun and Clarke, 2006).

In the course of data coding, analysis and interpretations, themes emerged that informed the various categorizations into key factors that shaped CSR in sub-Saharan Africa. Participants' responses were carefully analysed and articulated into key social responsibility issues (i.e. themes and sub-themes) including: government regulatory issues, environment, sustainability, legislation, international guidelines/standards, labour, community, organizational legitimacy, voluntary practice, mandatory disclosure, role of civil society, industry issues, communication, socio-cultural and political, and the role of media. This enabled a code book to be developed and populated with themes and sub-themes that emanated from the analysis of participants responses in an open catalogue. Secondly, the axial coding showed how the identified themes (i.e. assumed themes) emerged from the analysis, using the words of interview participants as a basis for constructing meanings from themes. The outcome of the coding and analysis process resulted in the emergent of thematic categories / constituents presented as the study findings (see section 4). The sheet accounted for the number of times or the frequency of the word/ meaning it occurred from the interview participants.

This study utilized data triangulation in relation to space i.e. collecting data at more than one site and persons i.e. collecting data from more than one set of individuals (Hussein, 2009., Ammenwerth et al, 2003). These types of data triangulation come as a result of the idea that the robustness of data can vary based on the people involved in the data collection process and the setting from which the data were collected (Hussein, 2009). Triangulation via data sources involves a wide range of informants where individual viewpoints and experiences can be verified against others and, ultimately, a rich picture of the attitudes, need or behaviour of those under scrutiny may be constructed based on the contributions of a range of people (Shenton, 2004). In this qualitative research, data was sourced from different participants at senior and different levels of national governments of different countries. In other to ensure reliability of the study data, the researcher interviewed participants from two broad categories namely; parliamentarians in national parliaments of selected countries (who are the policy makers) and executive cabinet members (who are policy implementers). As Humbe (2009) points out, data sources from different categories of personnel also constitute a form of triangulation.

\section{Findings and discussions}


The emerging themes are results of the structural thematic analysis conducted for this study. Thematic analysis, as used in the present study, allowed the researcher in identifying the significant elements, manifested themes, and the emergent attributes emerging from the responses of the experts within the organization. As such, four themes were accounted from the interviews of the participants in sub-Saharan Africa. The themes that emerged from the responses of the 15 participants allowed the development of the structural descriptions of the phenomenon of CSR implementation within the context of the sub-Saharan African companies.

The four themes that emerged in the analysis are (a) Status of CSR implementation in Sub-Saharan Africa, (b) Outcome of Absence of National CSR Policy, (c) Motivational factors of CSR implementation among companies, and (4) Characteristics of CSR reporting in subSaharan Africa.

Seven categories emerged in the analysis, which reflects the status of CSR implementation based from the perspective of government officials from the respective countries involved in the study. The majority of the participants revealed that while CSR has not been a formal national policy in these countries, the participants revealed that CSR framework has been mainstreamed in government constitutions. In particular, South African participants indicated the right-based policy as a broad framework of CSR. Participants from Ghana and Nigeria viewed CSR as a moral obligation, which is influenced by international advocacy of right-based framework for development. The majority of these participants reported that CSR is a company initiative in compliance with the international code of business conduct.

Furthermore, 11 participants articulated the involvement of civil society and nongovernment organizations in the CSR activities of business sectors. In South Africa, participants articulated advantages and disadvantages of involving civil society groups and NGOs. These participants revealed that some groups used their influence to corrupt the allocation of the companies for the communities while other groups may have good leadership and motives but are financially dependent with the corporations for their organizational operations.

Eight of the participants revealed that while CSR framework has been mainstreamed in the government system, regulations of the conduct are based on sectoral and procedural needs. The government regulations are limited within mining, timber, and labour sectors and within procurement dimension. Finally, CSR implementation processes in these countries observe the changes of historical and political event. Table 2 shows the result. 
Table 2 Thematic Category 1: Status of CSR implementation in Sub-Saharan Africa

\begin{tabular}{lcc}
\hline \multicolumn{1}{c}{ Thematic Categories/Constituents } & $\begin{array}{c}\text { No. of } \\
\text { participants } \\
\text { to offer this } \\
\text { experience }\end{array}$ & $\begin{array}{c}\text { Percentage } \\
\text { (\%) of } \\
\text { participants } \\
\text { to offer this } \\
\text { experience }\end{array}$ \\
\hline Absence of CSR policy & 15 & $100 \%$ \\
$\begin{array}{l}\text { CSR framework is mainstreamed in government } \\
\text { constitution }\end{array}$ & 15 & $100 \%$ \\
$\begin{array}{l}\text { CSR is a company initiative actions to comply } \\
\text { with international code of business conduct } \\
\begin{array}{l}\text { CSR implementation emanates from right-based } \\
\text { policy framework }\end{array}\end{array}$ & 15 & $100 \%$ \\
$\begin{array}{l}\text { Involvement of civil society and NGO } \\
\text { (Partnership-based Approach) }\end{array}$ & 11 & $73 \%$ \\
$\begin{array}{l}\text { Approach of CSR is based on sectoral (e.g., } \\
\text { mining, timber, labour) and procedural (e.g., } \\
\text { procurement) needs } \\
\begin{array}{l}\text { CSR recognition observes historical and political } \\
\text { process }\end{array}\end{array}$ & 8 & $53 \%$ \\
\hline
\end{tabular}

While companies in these countries voluntarily implement CSR, the absence of a national CSR policy posed several challenges. These challenges are listed in table 3.

Table 3 Thematic Category 2: Outcome of Absence of National CSR Policy

\begin{tabular}{lcc}
\hline \multicolumn{1}{c}{ Thematic Categories/Constituents } & $\begin{array}{c}\text { No. of } \\
\text { participants } \\
\text { to offer this } \\
\text { experience }\end{array}$ & $\begin{array}{c}\text { Percentage } \\
\text { (\%) of } \\
\text { participants } \\
\text { to offer this } \\
\text { experience }\end{array}$ \\
\hline Unregulated CSR Activities & 15 & $100 \%$ \\
Absence of punishment and reward system & 15 & $100 \%$ \\
$\begin{array}{l}\text { Difficulty in assessing the relevance of CSR } \\
\text { programs in national development }\end{array}$ & 15 & $100 \%$ \\
$\begin{array}{l}\text { Difficulty in monitoring and evaluating CSR } \\
\text { company initiatives }\end{array}$ & 15 & $100 \%$ \\
\hline
\end{tabular}


Companies are using the standards of international accrediting bodies

Absence of holistic government CSR agenda

15

$100 \%$

Shares revenues earned from communal resources

15

$100 \%$

Less involvement of local government units

14

$93 \%$

Unsustainable CSR approach

10

$67 \%$

Communities perceived that companies are more responsive to their needs than the government

(transfer of felt obligation)

Local communities as partners in development

effort

9

$60 \%$

Fulfilment of government unaccomplished services

8

$53 \%$

The participants from the sub-Saharan countries reported that the motivational factors that drive the CSR implementation are listed in table 4.

Table 4 Thematic Category 3: Motivational factors of CSR implementation among companies

\begin{tabular}{lcc}
\hline \multicolumn{1}{c}{ Thematic Categories/Constituents } & $\begin{array}{c}\text { No. of } \\
\text { participants } \\
\text { to offer this } \\
\text { experience }\end{array}$ & $\begin{array}{c}\text { Percentage } \\
\text { (\%) of } \\
\text { participants } \\
\text { to offer this } \\
\text { experience }\end{array}$ \\
\hline $\begin{array}{l}\text { CSR as a strategy to influence market } \\
\text { (maximization of profits) }\end{array}$ & 15 & $100 \%$ \\
$\begin{array}{l}\text { Achievement of smooth business operation } \\
\text { (business sustainability) }\end{array}$ & 15 & $100 \%$ \\
$\begin{array}{l}\text { Compliance of the social norms } \\
\text { Fulfilment of code of business conduct }\end{array}$ & 15 & $100 \%$ \\
$\begin{array}{l}\text { Compliance of international business accrediting } \\
\text { standards (e.g. ISO) }\end{array}$ & 15 & $100 \%$ \\
\hline
\end{tabular}


Generally, CSR has been used by companies to earn publicity and consequently achieve a good corporate image to secure their organizational legitimacy. At the country-level, all participants indicated that reporting in their countries is made voluntarily. However, at the international level, multinational companies that seek international recognition are mandated to report their CSR activities including the relevance of their work. All participants reported that voluntary reporting scheme has been limited to financial accomplishments (e.g. allocation of CSR programs) rather than issue-based accomplishments. Table 5 shows the result.

Table 5 Thematic Category 4: Characteristics of CSR reportage in sub-Saharan Africa

\begin{tabular}{lcc}
\hline \multicolumn{1}{c}{ Thematic Categories/Constituents } & $\begin{array}{c}\text { No. of } \\
\text { participants } \\
\text { to offer this } \\
\text { experience }\end{array}$ & $\begin{array}{c}\text { Percentage } \\
\text { (\%) of } \\
\text { participants } \\
\text { to offer this } \\
\text { experience }\end{array}$ \\
\hline $\begin{array}{l}\text { Reporting is voluntary at country-level } \\
\begin{array}{l}\text { Reporting is financial-based accomplishment than } \\
\text { issue-based }\end{array}\end{array}$ & 15 & $100 \%$ \\
$\begin{array}{l}\text { Reporting is mandatory at international level (e.g., } \\
\text { ISO accreditation) }\end{array}$ & 15 & $100 \%$ \\
$\begin{array}{l}\text { CSR report is a mechanism to leverage } \\
\text { competition } \\
\text { CSR report is a mechanism for transparency }\end{array}$ & 7 & $47 \%$ \\
$\begin{array}{l}\text { Involvement of media } \\
\text { Use of communication materials for reporting and } \\
\text { advocacy }\end{array}$ & 2 & $40 \%$ \\
\hline
\end{tabular}

$\underline{\text { Status of CSR implementation in sub-Saharan Africa }}$

From the analysis as presented in table 1, three key factors explain the status of CSR implementation in sub-Saharan Africa. These are:

* Absence of national CSR policy

* CSR framework is mainstreamed in government constitution

* CSR is company initiative actions to comply with international code of business conduct.

These findings explain the status of CSR implementation in sub-Saharan Africa. All 15 participants interviewed in South Africa, Ghana and Nigeria agreed that there is no formal 
policy framework that addresses CSR issues in the sub-region. Participants however were unanimous that the framework for CSR, in whatever form that it exists in the sub-region is mainstreamed in government constitution.

Outcome of absence of National CSR policy

From table 3 as outlined above, while companies in sub-Saharan Africa voluntarily implement CSR, it is evident that the absence of a national CSR policy posed several challenges that shape the practice in the sub-region. CSR is receiving great attention in the western society. The European Commission (2011) has asked member states to have national CSR policy frameworks as a way of promoting CSR in the EU. Other regions of the world are embracing CSR culture by encouraging corporations through national regulations, to embed CSR in their overall business strategy and activities. From the research evidence as seen in interviewees responses, no meaningful progress can be made in sub-Saharan Africa as for as CSR practices is concerned unless governments institute national CSR policies. One example of such comments was participant NG 04 from Nigeria who remarked as follows:

'To my knowledge, Nigeria does not have an existing CSR policy at the moment. Well basically it's been more or less the initiative of companies, especially those in the oil and gas sector and a few in the telecom sector have had to begin the initiatives. Also, companies engage in some voluntary initiatives as a result of pressure from host communities where they operate. And these initiatives revolve around gifts and donations, and the provision of some social amenities like building of classroom blocks, cottage hospitals and the like. But because there is no regulation on them, you know, no body monitors them, and sometimes these initiatives exists more on pages of newspapers than what is obtainable on the ground, yeah'.

Even Haigh and Jones (2005), agreed with the idea that regulatory pressure is a necessary driver of CSR. Where there are no policies, then companies are at liberty to draw up individual initiatives and set their individual agendas. Lack of policy frameworks means unregulated CSR activities. CSR practice to a large extent is determined by elements of legal and regulatory frame work. This position is supported by arguments made by Holland and Foo (2003). Furthermore, the absence of a national CSR policy means that there is an absence of punishment and reward system. As all 15 participants agreed, there can be no punishment and reward in the absence of guiding rules and regulation. This situation, interviewees reasoned, could increase corporations' impetus to undermining decent CSR practice. Elijido-Ten (2007) 
highlighted the importance of governmental sanctions as one of the significant factors influencing the discussion to incorporate superior environmental activities in corporate strategic plans. However, as some participants in Nigeria agreed, the reward and punishment of CSR is inherent in the practice by organizations.

Participants, particularly those from Nigeria and Ghana, were unanimous that lack of attention from governments and corporations is a major reason why host Communities withdraw the "Social License to Operate" from companies. 'Social license to operate' is an intriguing new phrase that has entered corporate parlance in recent years (Slack, 2008). Its meaning is not well defined, but corporations usually use it to refer to some kind of approval they must obtain from local communities in areas where they operate (as compared to the legal license they must obtain from governments) (Slack, 2008). According to Calain (2008), the concept of SLO (which is related but distinct from CSR) is the main operational objective of CSR at community level, giving the corporate industry its share of information legitimacy and additional operational space.

As noted by Kurlander (2001), local communities rely on the SLO to hold Organizations accountable for their actions or inactions in their communities. From participants' responses, it appears that where local communities perceive that an organization is not behaving responsibly, the SLO is withdrawn with consequences for corporate legitimacy and viability (see for example, Idemudia, 2009).

Other challenges revealed by the analysis of interviewees' responses are the twin difficulty in assessing the relevance of CSR programmes in national development and difficulty in monitoring and evaluating CSR company initiatives. All participants agreed that without institutional frameworks to regulate CSR, it appears extremely difficult to attempt to asses or even monitor and evaluate CSR programmes initiated by companies. As one participant from Nigeria (NG 01) notes:

"Yeah, like I said, policies in whatever form, as opposed to CSR, does not exist. It's almost a matter of utmost goodwill, it does not exist. CSR is operated by goodwill. And so, the level of compliance, to measure the level of compliance would be a little bit difficult to determine."

These revelations are supported by the literature. For example, Newell (2005) argues that a significant limitation of many existing CSR approaches is that while they encourage responsible business to go beyond compliance; they provide few checks and balances on the operations of irresponsible business for which strategies of regulations, sanction and protest continue to be key drivers of change (See also Gokiene and Dagiliene, 2011). 
From table 3, the results confirm that all participants interviewed in the three subSaharan African countries decried the absence of a holistic government CSR agenda. The absence of a holistic CSR agenda is another major outcome of absence of national CSR policy framework in sub-Saharan Africa countries. The majority of the participants, particularly those from Nigeria and Ghana agreed that a holistic national CSR agenda is imperative if the subregion is to make any headway in this fast growing phenomenon of CSR. A holistic CSR agenda will define what CSR is, and what its practice should be. The view by these participants is supported by the literature as scholars such as Bichta (2003); Standing (2007) and Young and Marais (2011) all related the need for national CSR policy through regulation, just as Emeseh et al (2010) warned of the dangers of non-regulation to the practice of CSR. However, South African participants were satisfied that the mainstreaming of CSR in the South African government legislations was adequate to advancing the CSR course in the country.

From the study findings, all 15 participants are unanimous that companies are using the standards of international accrediting bodies as a means of leveraging their corporate reputation. The question now is: how effective and applicable are these standards aimed at advancing the social, ethical and environmental performance of organizations, particularly in the context of sub-Saharan Africa with different socio-economic, cultural and political settlings? The study findings by Helg (2007), that most of the management tools and institutional models exported from western society to other regions of the world (including subSaharan Africa) may be ineffective, is quite apt here (see also Giannarakis et al (2011); BeckerOlsen et al (2011).

Another major thematic category that emerged from the data analysis is that in most of sub-Saharan African countries, revenues earned from communal resources are shared amongst the various tiers of governments. In particular, participants from Nigeria revealed that government holds a majority interest in the oil and gas industry (which is the country's economic mainstay), and as such government is unwilling to enforce a CSR policy which, rightly or wrongly, will have a backward impact on government funds. Furthermore, with no clear policy to regulate CSR practice, companies often take advantage of the voluntary nature of CSR practice to engage in activities which are not truly CSR (see Utting, 2005); Owonibi (2010) and Horigan (2009).

Motivational factors of CSR implementation among companies in sub-Saharan Africa

Despite the absence of national CSR policy frameworks in sub-Saharan African countries as revealed in this study, companies in the region have initiated various voluntary codes of CSR practices used to earn publicity and consequently achieve good corporate image to secure their 
organizational legitimacy. From interviewees' responses, it appears most companies in subSaharan Africa that engage in CSR practices do so with the aim of creating a conducive business environment that will enable them to maximize profit. The motivation to influence markets through voluntary self-drawn CSR initiatives was evident in most of the participant's responses, particularly those from Nigeria and Ghana. These findings are consistent with studies in the social responsibility literature (see for example, D’ Amato et al, 2009; Ite, 2007a; Perez-Batres et al, 2011 and Kercher, 2007.

Most of sub-Saharan African participants were unanimous that companies in the subregion use CSR as a tool of compliance with social norms. However, participants from South Africa in particular indicated the right - based policy as a broad framework of CSR.

According to these participants, most of the CSR activities that companies engaged in South Africa were geared towards correcting social disparity (in-harmony) brought about by the pre-1994 apartheid era. With the return of 'true democracy' in 1994, the need to address the poverty-gap, particularly between the whites and black South Africans, saw the enactment of the Broad Based Black Economic Empowerment (BBBEE) Law (2003). But these rights are rooted on social norms in South African society, and these norms can be linked to the kind of legitimacy that organizations enjoy through the social license to operate. Studies by O’Donovan (2002); Vourvachis (2008); Lin-Hi (2010); Deegan (2000); Haji and Ghazali (2011) supports these arguments.

\section{Characteristics of CSR reporting in sub-Sahara Africa}

In this section, the characteristics of CSR reporting in Sub-Saharan Africa are discussed. From the analysis of interviewees' responses, as outlined under table 4, three key thematic categories/constituents emerged as characteristics that shape CSR reporting in SubSaharan Africa. These are (a) Reporting is voluntary at country level, (b) Report is financialbased accomplishment than issue-based and (c) Reporting is mandatory at international level (e.g. ISO accreditation), but at country level, CSR is voluntary. As Haslam (2007) notes, CSR has been implemented through voluntary codes of conduct. Participants agreed that making the practice mandatory, for instance, will scare away potential (and actual) investors. As stated by one participant from Ghana (GH 01):

"Like I did say initially, some form of regulation could help promote CSR in Ghana, not an outright CSR law, but giving it some institutional support I think. Making CSR practice will be quite difficult, if we are not careful, ehmm we shall scare companies away. It will look like another taxation monitoring system, so I think that government should play supportive role by creating the enabling environment for CSR to strive”. 
While all 15 participants agreed that CSR is practiced voluntarily, the majority however, suggested that disclosure of social and environmental activities should be mandatory. Furthermore, mandatory practice of CSR could lead to window dressing by corporations and often gives the impression that the corporate sector in general is seriously engaged, whereas the reality is different (Utting, 2005). From the CSR literature, the voluntary approach to CSR reporting implies a more discretionary act on the part of companies as they consider their role and impact across a wide range of corporate activities (Garvey and Newell, 2005; Carroll, 1991).

While participants generally are unanimous that the practice of CSR should be voluntary, the majority of participants from Ghana and Nigeria favours a combination of voluntary practice and mandatorily disclosing such voluntary activities. The arguments advanced by these category of respondents is that there are implications of voluntary CSR practice in a developing region (like sub-Saharan Africa) context which raise doubts about the effectiveness of the measure. Studies by Owonibi (2010); Harigan (2009), and Hine and Preuss (2009) seem to support this line of argument as most CSR initiatives are seen as part of a risk management strategy to pre-empt regulation.

At the organizational level, CSR is largely practiced and reported voluntarily (Rodriguez and Le Master, 2007). A major advantage to companies regarding the current practice is that they set the agenda on what CSR is and what is not. Accordingly, companies have had to engage in CSR practices with different goals in mind. For instance, a common argument in the corporate governance and CSR literature is the fact that most CSR reporting is financial-based accomplishment than issue-based. From the data analysis findings, the majority of respondents agreed that financial considerations are a pervasive characteristic of CSR reporting in Sub-Saharan Africa. While empirical studies have found mixed results on the relationship between profitability and CSR disclosure (Ponnu \& Maurice, 2009), companies generally consider CSR related expenses as additional, often time avoidable, cost (see for instance, Lucas et al, 2009).

The last thematic category that characterizes CSR reporting in sub-Saharan Africa is that reporting is mandatory at international level (for instance, ISO accreditation). While international guidelines/standards is one of the a priori thematic frameworks or codes set before the actual field work of this study, the findings that reporting is mandatory at the international level was unexpected. However, while international accountability guidelines and standards have provided MNCs with ways to systematically assess, measure and communicate their social and environmental performance (see Gilbert et al, 2010), it seems, however, that the 
applicability and usefulness of these multifarious standards, which differ in detail, leaves much to be desired. Whereas, majority of participants are unanimous about the mandatory compliance objective to international guidelines by companies in sub-Saharan Africa, they seem, however, not to be aware whether or not such guidelines are effectively implemented.

\section{Mainstreaming of CSR framework in government constitution}

One key category that emerged from the analysis of respondents' transcripts is that CSR framework is mainstreamed in government constitution. While all 15 participants agreed to varying degrees, that social and environmental considerations are built into most of the respective countries constitutions, South African participants are more persuasive about the mainstreaming of this social phenomenon into national legislations. As a voluntary practice, CSR is practiced and reported differently among countries. Accordingly, governments incorporate CSR issues into their various laws. In South Africa, for instance, the majority of participants articulated that the country does not have a specific CSR law, but it is written into most of its national laws like labour (e.g. the BBBEE Act), environment, consumer protection, etc.

A review of the responses of some of the South African participants reveals the weight which they attached to the issue of not having a stand-alone CSR policy.

"I would not say that we have a separate or individual corporate social responsibility policy, on its own. I think it is incorporated into many of the legislations that we have. It is not a standalone policy." (Participant SA 01)

"Policy in general terms, yes. But specifically for CSR, I do not think so. In South Africa, there are a number of policies which indirectly impact on corporate social responsibility, like the labour and empowerment laws, and so on”. (Participant SA 02)

While CSR practice is not yet visible in countries like Nigeria and Ghana, the current CSR practice is, never-the-less, mainstreamed in the national constitution particularly those relating to oil and gas operation in Nigeria, and timber and mining in Ghana.

\section{Conclusions}

The present study highlighted the current state of CSR implementation in sub-Saharan Africa. The majority of participants revealed that while CSR has not been a formal national policy in these countries, they contended that CSR framework has been mainstreamed in government constitutions. In particular, South African participants indicated the rights-based policy as a broad framework of CSR. This is, however, not surprising giving the socio-cultural history of 
South Africa, coming from the pre-1994 apartheid regime that caused huge social disparity amongst the population. However, participants from Nigeria and Ghana viewed CSR from a moral obligation perspective, which is influenced by international advocacy of right-based framework for development.

Furthermore, CSR as revealed by this study is a company initiative in compliance with international code of business conduct. Lack of national CSR policy meant that organizations are at liberty to take individual initiatives, which often do not reflect corporate social responsibility practice. This create a number of challenges to government, companies and host communities where companies operate, with the resulting difficulty in assessing, monitoring and evaluating CSR company initiatives. From a motivational perspective, the study argues that achievement of smooth business operation and other social (legitimacy) based objectives with an underlying profit maximising motive are prominent factors why companies engage in CSR in sub-Saharan Africa.

CSR reporting in sub-Saharan Africa is characterised by voluntary reporting at countrylevel with financial-based accomplishment, while at the international level, companies mandatorily report in order to secure international accreditations (e.g. ISOs). While the issue of bias and small number of countries involved in the study may constitute some limitations, this study could have policy implication for both executive and national parliaments in developing countries in initiating appropriate legal framework and enabling legislations to support CSR practice. In addition, the necessary regulatory institutions and monitoring agencies should be established to ensure compliance with relevant guidelines and code of good business conduct in the context of local environment. Furthermore, Reporting benchmarks should be established by the regulatory authority to ensure performance measurement and feedback. Future research could examine the suitability of international accountability and environmental standards and guidelines adopted by companies in the context of sub-Saharan Africa.

\section{References}

Adegbite, E; Amaeshi, K and Amao, O (2012) The Politics of shareholder activism in Nigeria, Journal of Business Ethics Vol. 105 pp389-402 Springer

Adeyeye, A (2011) Universal standards in CSR: are we prepared? Corporate Governance, vol.11 (1)

pp.107-119

Adeyanju, O (2012) An assessment of the impact of corporate social responsibility on Nigerian society: The examples of banking and communication industries. 
Universal Journal of Marketing and Business Research (UJMBR). Vol. 1(1) Pp.17- 43

Albareda, L; Lozano, J; Tencati, A; Middttun, A, and Perrini, F (2008) The changing role of governments in Corporate Social Responsibility: drivers and responses Business Ethics: A European Review, Vol. 17 (4) Pp. 347-363

Amaeshi, K; Adi, B; Ogbechie, C and Amao, O (2006) "Corporate Social Responsibility in Nigeria: Western mimicry or indigenous practice”. Journal Of Corporate Citizenship Vol. $24 \quad$ (winter) Pp. 83-99.

Ammenwerth, E; Iller, C and Mansmann, U (2003) ''Can evaluation studies benefit from triangulation?’' A case study. International Journal of medical Informatics, vol. 70 (2003) pp237-248

Amran, A and Devi, S (2007) Corporate Social Reporting in Malayisa: A Political Theory Perspective Malaysian Accounting Review Vol. 6 (1) PP 19-44

Argandona, A \& Hoivik, H.V (2009) Corporate social Responsibility: one size does not fit all.

Pp.1- 19

Collecting evidence from Europe. IESE Business School Working Paper No. 834

Aronson, J (1994) A pragmatic view of thematic analysis. The Qualitative report vol.2 (1). Spring

http://www.nova.edu/ssss/QR/BlackIssues/QR2-1/aronson.html (accessed on 13/12/2011).

Banuri, T and Spanger -Siefried, E (2001) The Global Compact and the Human Economy. Journal of Human Development Vol. 2 (1) Pp. 7-17

Becker - Olsen, K; Taylor, C; Hill, R and Yalcinkaya, G (2011) A Cross-Cultural Examination of Corporate Social Responsibility Marketing Communications in Mexico and the United States: Strategies for Global Brands. Journal of International Marketing: Vol. 19 (2) pp. 30-44.

Bichta, C (2003) Corporate Social Responsibility. A role in Government policy and

Regulation? University of Bath School of Management Centre for the study of regulated industries Research report 16 Available on-line at www.bath.ac.uk/management/cri/pubpdf/research_Reports/16_Bichta.pdf (accessed on 23/04/11).

Boafo-Arthur, K (2008) Democracy and Stability in West Africa. The Ghanaian Experience.

Claud Ake Memorial Papers No. 4 Uppsala University. Available on-line at: http://www.pcr.uu.se/digitalAssets/18/18579_CAMP4-Kwame.pdf (Accessed

26/10/12)

Bowen, G.A (2005) Preparing a qualitative research-based dissertation: Lessons Learned The Qualitative Report Volume 10 (2) Pp. 208-222

Braun, V and Clarke, V (2006) Using thematic analysis in psychology, Qualitative research in psychology, vol. 3 (2) pp. 77-101

Breitbarth, T; Harris, P; and Aitken, R (2009) Corporate social responsibility in the European Union: a new trade barrier? Journal of Public Affairs Vol. 9 (2009) Pp. 239-255

Calain, P (2008) Oil for health in sub-Saharan Africa: health systems in a 'resource curse' environment Globalization and Health Vol. 4(10) Pp. 1-17

Calderon, M (2011) CSR in Latin America and South East Asia: Analysis of the corporate communication of top local companies. Int'l Research Journal of Finance and

Economics Vol. 73(2011) Pp. 56-74

Carroll, A.B (1991) The pyramid of corporate Social Responsibility: Toward the moral management of organizational stakeholders in: Business Horizons, vol.34 (4) pp.39 48 
Carroll, A.B and Shabana, K (2010) the business case for corporate social responsibility: A review of concepts, Research and practice. Int'l journal of management reviews. Vol.

12 (1) Pp. 85-105

Casanova, L; and Dumas, A (2009) Corporate Social Responsibility and Latin American multinationals: Is poverty a business issue? Universia Business review 2(1) Pp. 132145

Chambers, E; Chapple, W; Moon, J and Sullivan, M (2003) Corporate Social Responsibility

in Asia: $\quad$ A seven country study of CSR website reporting Research paper series International Centre for Corporate Social Responsibility Pp. 1- 47

Chen, W; and Hirschheim, R (2004) A paradigmatic and methodological examination of Information Systems Research from 1999 - 2001 Info Systems Journal Vol. 14 pp $197-235$

D’Amao, A ; Hendersen, S and Florence, S (2009) Corporate Social Responsibility and Sustainable Business. Aguide to leadership tasks and functions Center for creative leadership, Greensboro, North Carolina www.ccl.org/leadership/pdf/research/corporatesocialresponsibility.pdf (accessed on 23/04/2011)

Deegan, C (2000) Firms’ Disclosure reaction to major social incidents: Australian Evidence.

Accounting forum, Vol. 24(1) Pp.101-130

Delmas, M and Montiel, I (2008) The diffusion of voluntary international management standards: $\quad$ Responsible care, ISO 9000 and ISO 14001 in the chemical industry. Policy studies journal, $\quad$ vol.36 (1) pp.65-93

Devers, K; and Frankel, R (2000) Study design in qualitative research - 2: sampling and data collection strategies. Practical advice Education for Health Vol. 13(2) Pp. 263-271

Dias, A (2007) Human Rights Accountability of Minerals Development Industry http://www.greenleaf-publishing.com/productdetail.kmod?productid=2662 accessed on $27 / 04 / 2011$

Elijido - Ten, E (2007) Applying stakeholder theory to analyze corporate environmental performance: Evidence from Australian listed companies. Asian Review of Accounting, Vol. 15(2) PP 164-184.

Elijido-Ten, E; Kloot, L and Klarkson, P (2010) Extending the application of stakeholder influence strategies to environmental disclosures AAA Journal Vol. 23(8) Pp.1032-1059 Emeseh, E; Ako, R; Obokok, P and Ogechukwu, L (2010) Corporations, CSR and selfregulation: what lessons from the global financial crisis? German Law Journal Vol 11(2) pp 230-259

European Commission (2011) Communication from the Commission to the European Parliament, The Council, The European Economic and Social Committee and The Regions. Available on-line at eur- lex.europa.eu/lexUriserv/lexUriserv.do?uri=COM.2011:0681:FIN:EN:PDF (accessed on 05/01/2012)

Eweje, G (2007) Multi-national Oil Companies’ CSR Initiatives in Nigeria: The skepticism of stakeholders in host communities. Managerial Law Vol. 49(5 and 6) Pp. 218-235

Fink, A (2000) The role of the researcher in the qualitative research process. A potential barrier to Archiving Qualitative Data Forum: Qualitative Social Research, vol.1 (3) pp.1-11 Fox, T; Ward, H and Howard, B (2002) Public Sector roles in strengthening CSR: A base line study The World Bank CSR practice Oct Available on-line at pubs.iied.org/pdfs/16017IIED.pdf (accessed on 28/04/2011). 
Garvey, N and Newell, P (2005) Corporate accountability to the poor? Assessing the effectiveness of community based strategies. Development practice Vol. 15 (3 \& 4) Pp. $389-404$

Giannarakis, G. Litinas, N and Sariannidis, N (2011) Evaluation of corporate social Responsibility Performance standards. African Journal of Business Management Vol. 5 (17) pp. 7367- 7373

Gilbert, D; Rasche, A and Waddock, S (2010) 'Accountability in a Global Economy: the Emergence

of international Accountability Standards'. Business ethics quarterly, Vol. 21(1) Pp.23 - 44

Gokiene, L and Dagiliene, R (2011) Valuation of Corporate Social Responsibility reports Economics and Management Vol. 16 (2011) Pp.21- 26

Global Reporting Initiative (2010) Carrots and sticks - Promoting Transparency and

Sustainability: An update of trends in voluntary and mandatory approaches to

sustainability reporting. Available on-line at

https://www.globalreporting.org/resourcelibrary/carrots-And-sticks- promotingtransparency-and-sustainability.pdf (Accessed on 18/02/11)

Global Reporting Initiative (2011) A new phase: the growth of sustainability reporting. GRI 's year in review. Available on-line at https://www.globalreporting.org/resourcelibrary/GRIYear-In- $\quad$ Review-2010-2011.pdf (Accessed on 25/10/12)

Groenewald, T (2004 ) A phenomenological Research Design illustrated. International journal of Qualitative methods, vol.3 (1) pp1-26

Guest, G; Bruce, A and Johnson, L (2006) How many interviews are enough? An experiment with data saturation and variability Fields methods, vol. 18(1) pp. 59-82

Haji, A and Ghazali, N (2012) The influence of the financial crisis on corporate voluntary disclosure: some Malaysian evidence. International Journal of Disclosure and Governance Vol 9(2012) Pp. 101-125

Hale, E; Treharne, G and Kitas, G (2007) Qualitative Methodologies 1: asking research questions with reflexive insight. Musculoskeletal care, vol. 5(3) pp.139-147

Hamann, R and Acutt,N (2003) How should civil society (and the government) respond to Corporate Social Responsibility? A critique of business motivations and the potential for partnerships Development Southern Africa Vol. 20 (2) Pp. 255-270

Hartman, L and Painter-Morland, M (2007) Exploring the Global Reporting Initiative (GRI) guidelines as a model for triple bottom-line reporting. African journal of Business

ethics Vol. 2(1) Pp.45-57

Haslam, P.A (2007) Is Corporate Social Responsibility a constructivist Regime: evidence from Latin America. Global Society Vol. 21(2) Pp. 269 - 296

Helg, A (2007) Corporate Social Responsibility from a Nigerian perspective Master thesis, management and Organization Handelshog Skolan Vid Goteborgs universities.Available online at https://gupea.ub.gu.se/bitstream/2077/4713/1/07.23.pdf (Accessed on 24/02/11)

Herrmann, K (2004) Corporate Social Responsibility and Sustainable Development: the EU Initiative as a case study. Indiana Journal of Global legal studies Vol. 11(2) Pp. 205232

Hignett, S and Wilson, J (2004) The role for qualitative methodology in ergonomics: a case study to explore theoretical issues. Theoretical Issues in Ergon. Sci. vol 5(6) pp473493 Nov/Dec

Haigh, M and Jones, M (2005) The drivers of corporate social responsibility: A critical review. Ashridge Business School, UK. Available on-line at: 
http://www.ashridge.org.uk/website/IC.nsf/wFARATT/TheDriversof corporate social responsibility: A critical Review/\$file/TheDriversofcorporatesocialresponsibility.pdf (Accessed on 28/08/11)

Hine, J and Preuss, L (2009) "Society is out there, Organization is in here”; on the perceptions of

\section{Business}

Corporate Social Responsibility held by different management groups Journal of

Ethics Vol. 88 Pp. 381-393.

Hoepfl, M (1997) Choosing qualitative research: A primer for Technology Education Researchers. Journal of Technology Education, Vol.9 (1) pp.47 - 63

Holland, L. And Foo, Y (2003) Differences in environmental reporting practices in the UK and the U.S: The legal and regulatory context. The British Accounting review, Vol. 35(1) PP1-18

Hopkins, M (2004) Corporate Social Responsibility: an issue paper. Policy Integration Dept. World Commission on social Dimension of Globalization International Labour Organization Geveva. Working paper No. 27 Available on-line at http://195.130.87.21:8080/dspace/bitstream/123456789/1193/1/Corporatesocialrespon sibilitya nissuepaper.pdf (Accessed on 14/03/2011)

Horrigan, B (2007) $21^{\text {st }}$ Century corporate social responsibility trends - An emerging comparative body of law and regulation on corporate responsibility, governance and sustainability. Macquarie Journal of Business Law, Vol. 4(2007) pp. 85-122

Humbe, A (2009) Technique triangulation for validation in directed content analysis. International Journal of qualitative methods Vol. 8(3) pp34 - 51

Hussein, A (2009) The use of triangulation in social science research: can qualitative and quantitative methods be combined? Journal of comparative social work vol.1 (2009) Pp. $1-12$.

Hycner, R (1985) Some guidelines for the phenomenological analysis of interview data. Human studies Vol. 8 (1985) Pp. 279 - 303

Idemudia, U (2009) Assessing corporate - community involvement strategies in the Nigerian oil industry: An empirical analysis. Resources Policy 34 pp133-141

Idowu, A.A (2008) Human Rights, Democracy and Development: The Nigerian Experience Research Journal of Internatıonal Studies - Issue 8, November Pp. 27- 41

Ikejiaku, B (2012) Consideration of ethical and legal issue of multinational corporations and sustainable development. Nordic Journal of Commercial Law Vol. 2012 (1) pp. 1 32

Ite, U (2007 a) changing times and strategies: Shell's contribution to sustainable Development in the Niger Delta, Nigeria. Sustainable Development Vol. 15 (1) Pp.1-14.

Ite, U (2007 b) Partnering with the state for sustainable Development: Shell's Experience in the Niger Delta, Nigeria. Sustainable Development, Vol. 15(4) Pp. 216-228.

Jamali, D and Mirshak, R (2007) Corporate Social Responsibility (CSR): Theory and practice in a developing country context. Journal of Business Ethics Vol. 72(3) Pp. 243-262

Janney, J; Dess, G and Forlani, U (2009) Glass Houses! Market Reactions to Firms Joining The UN

Global Compact. Journal Of Business Ethics Vol. 90 (3) Pp. 407 - 423.

Joseph, E (2002) Promoting corporate social responsibility Is market-based regulation sufficient? Institute for public policy research New Economy Pp.96-100 Available on-line at www.ippr.org/uploadedfiles/projects/NEWE250.pdf (Accessed on 12/02/11).

Kartadjumena, E; Hadi, D and Budiana, N (2011) The relationship of profit and corporate social Responsibility Disclosure (survey of manufacturing industry in Indonesia). $2^{\text {nd }}$ 
International conference on Business and economic research proceeding. Available on-line at $\quad$ http://econpapers.repec.org/paper/cms2icb11/2011-400.htm Accessed on 11/06/11

Kercher, K (2007) Corporate social responsibility: impact of globalization and international

business. Corporate Governance Journal. Available on-line at

http://epuublications.bond.edu.au/cgej/4 (Accessed on 13/04/11)

Kivuitu, M and Yambayamba, K. (2004) How can Corporate Social Responsibility deliver in

Africa? Insights from Kenya and Zambia International Institute for environment and

development No. 3 Jul Available on-line at http://pubs.iied.org/16006IIED.html

(Accessed on 11/02/11)

Kolk, A and Tulder, R.V (2002) The effectiveness of self-regulation: corporate codes of

conduct and child labour. European Management Journal Vol. 20 (3) pp 260-271

Kurlander, L (2001) Newmont mining: the social license to operate. Global Executive

Forum Centre for International Business Education \& Research Oct. Available on-

line at:

http://www.ucdenver.edu/academics/InternationalPrograms/CIBER/GlobalForumRep

orts/Documents/Newmont_Mining_Social_License.pdf (Accessed on 11/02/11)

Krauss, S (2005) Research Paradigms and Meaning Making: A Primer The Qualitative Report Vol. 10 (4) Pp. 758-770

Lin-Hi, N (2010) The problem with narrow-minded interpretation of CSR: why CSR has nothing to do with philanthropy. Ramon Llull Journal of applied ethics Vol. 1 (1) pp7995

Lucas, T; Cunningham, R and Lamberton, G (2009) Small Business Engagement with Sustainability in Regional Australia Journal of Economic and social Policy Vol. 13 (1) Pp. $1-17$

Magness, V (2006) Strategic posture, financial performance and environmental disclosure: An empirical test of legitimacy theory. Accounting, Auditing and Accountability Journal Vol. 19 (4) PP 540-563

Martin, S; Trask, J; Peterson, T; Martin, B; Baldwin, J and Knapp, M (2010) 'Influence of culture and discrimination on care-seeking behavior of elderly African Americans: A qualitative study’. $\quad$ Social Work In Public Health, Vol. 25 pp.311-326.

Mason, M (2010) Sample size and saturation in PhD studies using qualitative interviews.

Forum: Qualitative social research, vol. 11(3) pp. 1- 19.

Mehallow, C (2010) CSR Reporting: An insiders' update on the latest from GRI. Available on line at

http://www.triplepundit.com/2010/04/csr-reporting-gri-global-reporting-initiative/ (Accessed on 19/05/11)

Mendibil, K; Hernandez, J; Macgregor, S; University of Strathclyde, UK; Espinach, X.

Universitat de Girona, Spain; and Garriga, E. IESE Business School, Spain (2007) How can CSR practices lead to successful innovation in SMEs? Available on-line at http://www.kantakji.com/figh/Files/Companies/z132.pdf (Accessed on 09/02/11)

Mordi, C; Opeyemi, I and Ojo, S (2012) Corporate Social Responsibility and the legal regulation in Nigeria Economic Insights - Trends and challenges Vol. 54(1) Pp 1-

8

Muthuri, J (2012) Corporate Social Responsibility in Africa: Definitions, Issues and Processes. International Centre for Corporate Social Responsibility Royal Holloway

Nelson, J (2008) "CSR and public policy: New forms of engagement between business and government”. Corporate Social Responsibility Initiative Working paper No. 45

Available on-line at http://www.hks.harvard.edu/mrcbg/CSRI/publications/workingpaper_45_nelson.pdf

(Accessed on 11/12/10) 
Newell, P (2005) Citizenship, accountability and community: the limits of the CSR agenda International Affairs Vol. 81(3) Pp. 541-557, May

Obalola, M (2008) Beyond philanthropy: Corporate Social Responsibility in the Nigerian insurance Industry. Social Responsibility Journal Vol. 4(4) Pp. 538-548

Obemene, O (2012) Corporate Social Responsibility practices in mobile telecommunications Industry in Nigeria European Journal of Business and Management Vol. 4(8) Pp. 149-159

O’ Donovan, G (2002) Environmental disclosures in the annual report: Extending the applicability and predictive power of legitimacy theory Accounting, Auditing and Accountability Journal, Vol. 15 (3) 344-371.

Owonibi, A (2010) Why Nigerian companies equate CSR with media companies. Tribune business Nov 12 http://www.tribune.com.ng/index.php/tribune-business/13451-whynigerian- $\quad$ companies-equate-csr-with-media-campaign (Accessed on 10/11/11)

Pedersen, E (2011) All animals are equal, but.....management perceptions of stakeholder relationships and social responsibilities in multinational corporations. Business Ethics: A European Review Vol. 20 (2) Pp. 177-191 April.

Perrini, F (2007) Encouraging CSR in Italy: The Enabling Role of Government in Mandating, Motivating, and supporting Responsible Business Practice. Corporate Social Responsibility Initiative Working Paper No.35

Perez-Batres, l; Miller, V and Pisani, M (2011) Institutionalizing sustainability: an empirical study of guidelines.

corporate registration and commitment to the United Nations global compact

Journal of cleaner production Vol. 19 Pp. 843-851.

Ponnu,C and Okoth, M (2009) Corporate Social Responsibility disclosure in Kenya: The Nairobi Stock Exchange. Africa Journal of Business Management Vol. 3 (10) pp. 601-608

Preuss, L; Haunschild, A and Matten, D (2006) Trade Unions and CSR: a European research agenda. $\quad$ Journal of Public Affairs. Vol. 6 pp. 256 - 268

Prieto-carron, M; Lund-Thomsen, P; Chan, A; Muro, A and Bhushan, C (2006) Critical perspectives on CSR and development; what we know, what we don't know, and what we need to know. International Affairs Vol. 82 (5) Pp. 977-987.

Rea, M (2011) King III and GRI + 12: A 2011 review of sustainability reporting in South Africa.

http://www.csap.co.za/Documents/Research/King_III_and_GRI_12_Research_Report

. pdf

(Accessed on 09/02/2012)

Reed, D (2002) Employing normative stakeholder theory in developing countries A critical theory perspective Business Society, vol. 41(2) pp. 166-207

Rodriguez, L and LeMaster, J (2007) Voluntary Corporate Social Responsibility Disclosure:

SEC 'CSR Seal of Approval'. Business and Society, vol.46 pp 370-384

Rosser, A and Edwin, D (2010) The politics of corporate social responsibility in Indonesia. The Pacific Review Vol. 23 (1) Pp.1- 22

Ruggie, J.G (2007) Business and Human Rights: The evolving International Agenda. Corporate Social Responsibility Initiative, Working Paper No. 31

Russell, C and Gregory, D (2003) Evaluation of qualitative research studies. Evidence based nursing, vol.6 (2) pp. 36-40.

Rwabizambuga, A (2007) Negotiating CSR policies and practices in developing countries: an examination of the experiences from the Nigerian oil sector. Business and society

review. $\quad$ Vol.112 (3) pp407 - 430 
Ryan, F; Coughlan, M and Cronlin, P (2007) Step-by-step guide to critiquing research Part 2: qualitative research British Journal of Nursing Vol.16 (12) Pp. 738-744

Saunders, M; Lewis, P and Thornhill, A (2009) Research methods for Business students Fifth edition, $\quad$ Pp. 110-111, 115-116, 122-123, 127 \& 480 - 482

Scheffer, D and Kaeb, C (2012) The five levels of CSR compliance: The resiliency of corporate liability under the alien tort statute and the case for a counter-attack strategy in compliance theory. Berkeley Journal of International Law Vol. 29(1) Pp. 334-397

Selby, H and Kunateh, M (2009) Ghana: set up a national corporate social responsibility framework.

http://allafrica.com/stories/200905111486.html (accessed on 10th January, 2012)

Sharif, I (2010) 'Ghanaian opinions on democracy, inter-communal violence and conflict in sub- Saharan Africa' African Journal of Political Science and International Relations, Vol. 4 (4) Pp. 150 -163, April

Shen, W (2004) A comparative study on corporate sponsorships in Asia and Europe. Asia Europe Journal Vol. 2 (2) Pp283-295

Shenton, A (2004) Strategies for ensuring trustworthiness in qualitative research projects.

Education for information Vol. 22 (2004) pp. 63-75

Slack, K (2008) Corporate Social License and Community Consent Policy Innovations Available on-line

http://www.policyinnovations.org/ideas/commentary/data/000094 (Accessed on 14/09/11)

Standing, D (2007) Decent work places, self-regulation and CSR: From puff to stuff? Economic and social Affairs DESA Working paper No. 62. November Pp. 1 - 32

Steurer, R (2010): The role of governments in Corporate Social Responsibility: characterizing public policies on CSR in Europe; Policy Sciences, Vol. 43 (1) Pp. $49-72$

Sun, W; Stewart, J and Pollard, D (2010) Reframing Corporate Social Responsibility: Lessons from the Global Financial Crisis. Critical Studies on Corporate Responsibility, Governance and Sustainability, Volume 1 Pp. 4-5 and 65 Emerald Books

Transparency Benchmark (2010) The crystal: an initiative of the Ministry of Economic Affairs, Agriculture and innovation and the Dutch Association of Accountants. Available on-line at www.transparencybenchmark.nl

Tuodolo, F (2009) Corporate Social Responsibility: Between Civil Society and the Oil Industry in the Developing World. ACME: An International E-Journal for critical geographies. Vol. 8(3) pp. $530-541$

Utama, S (2007) Evaluation of supportive infrastructures for CSR reporting in Indonesia. Faculty of

Economics, University of Indonesia Available on-line at:

http://staff.ui.ac.id/internal/131803512/publikasi/20283PF.pdf (Accessed on 18/11/11)

Utting, P (2005) Corporate Responsibility and the movement of business Development in practice, $\quad$ vol. 15(3 \& 4) pp375-388

Uwuigbe, U and Egbide, B (2012) Corporate Social Responsibility Disclosures in Nigeria: A study of listed Financial Firms. Journal of Management and Sustainability Vol. 2(1) Pp.160-169

Vasilachis de Gialdino, I (2011). Ontological and Epistemological Foundations of Qualitative Research Forum: Qualitative Social Research, Vol.10 (2), Art. 30, Pp.1-25 Available on-line at http://nbn-resolving.de/urn:nbn:de:0114-fqs0902307. (Accessed on 13/03/2012) 
Vertigans, S (2012) CSR as corporate social responsibility or colonial structures return? A Nigerian case study International Journal of sociology and Anthropology Vol. 3(6) Pp. 159-162

Visser, W and Tolhurst, N (2010) The world guide to CSR: A country-by-country Analysis of corporate sustainability and reporting. Greenleaf publishing Limited. Available on-line

at $\quad$ www.greenleaf-publishing.com/worldguide (accessed on-line on 23 April, 2012)

Vourvachis, P (2008) In search of explanations for Corporate Social Reporting (CSR): An attempt to Revisit Legitimacy Theory Working Paper Series No. 16. In: British Accounting Association Annual Conference; 1-3 April http://eprints.kingston.ac.uk/id/eprint/4415 (Accessed on 1/2/11)

World Business Council for Sustainable Development (1998) Corporate Social

Responsibility: Meeting changing expectations. Available on-line at www.wbcsd.org/work-program/business-role/previous-work/corporate-socialresponsibility.aspx (Accessed on 12/05/13).

Young,S and Marais, M (2011) Could regulated CSR reporting in Australia lead to innovation? Available online at www.csrconnect.ed.com.au/2011/05/could-regulated-csrreporting-in- australia-lead-to-innovation/> (accessed on 8 August, 2012). 